\title{
Is COVID-19 an endothelial disease? Clinical and basic evidence
}

Celestino Sardu, MD, MSc, PhD 1,2; Jessica Gambardella, $\mathrm{PhD}_{3,4}$; Marco Bruno Morelli $\mathrm{PhD}_{4}$, Xujun Wang, MD4; Raffaele Marfella, MD, $\mathrm{PhD}_{1}$; Gaetano Santulli, MD, $\mathrm{PhD}_{3,4^{*}}$

1. Department of Advanced Medical and Surgical Sciences, University of Campania "Luigi Vanvitelli”, Naples, Italy;

2. Department of Medical Sciences, International University of Health and Medical Sciences "Saint Camillus", Rome, Italy;

3. Department of Advanced Biomedical Sciences, International Translational Research and Medical Education Academic Research Unit (ITME), "Federico II" University, Naples, Italy;

4. Department of Medicine, Albert Einstein College of Medicine, Wilf Family Cardiovascular Research Institute, Fleischer Institute for Diabetes and Metabolism (FIDAM), Montefiore University Hospital, New York, NY, USA.

*Corresponding Author: gaetano.santulli@einsteinmed.org 


\section{Abstract}

The symptoms most commonly reported by patients affected by coronavirus disease 2019 (COVID-19) include cough, fever, and shortness of breath. However, other major events usually observed in COVID-19 patients (e.g. high blood pressure, thrombosis, pulmonary embolism) seem to suggest that the virus is targeting the endothelium, one of the largest organs in the human body. Herein, we report both clinical and preclinical evidence supporting the hypothesis that the endothelium is a key target organ of COVID-19. 


\section{Introduction}

Coronavirus disease 2019 (COVID-19) represents a public health crisis of global proportions. Caused by SARS-CoV-2, which stands for severe acute respiratory syndrome coronavirus 2 , COVID-19 was first announced in December 2019 in Wuhan, the capital of China's Hubei province, and has since spread globally 1 . The symptoms most commonly reported include cough, fever, and shortness of breath. The pathophysiology of the disease explains why respiratory symptoms are so common: indeed, the virus accesses host cells via the protein angiotensin-converting enzyme 2 (ACE2)2, 3, which is very abundant in the lungs4. Nevertheless, ACE2 is also expressed by endothelial cells (ECs)5, 6, and other major clinical events usually observed in COVID-19 patients (e.g. high blood pressure7, thrombosis8, pulmonary embolism9) seem to suggest that the virus is targeting the endothelium, one of the largest organs in the human body 10.

\section{Pathogenesis of COVID-19}

SARS-CoV-2 uses a surface glycoprotein (peplomer) called spike to access host cells and ACE2 has been shown to be a co-receptor for coronavirus entry 11, 12. Therefore, the density of ACE2 in each tissue may correlate with the severity of the disease in that tissue $13-16$. Other receptors on the surface of human cells have been suggested to mediate the entry of SARS-CoV-23, including transmembrane serine protease 2 (TMPRSS2) 17 , sialic acid receptors 18,19 , and extracellular matrix metalloproteinase inducer (CD147, also known as basigin)20.

Intriguingly, all of these 4 receptors are known to be expressed by ECs21-24 (Figure 1). ACE2 remains the most studied of these receptors 16, 25-29: for instance, its genetic inactivation has been shown to cause severe lung injury in $\mathrm{H} 5 \mathrm{~N} 1$-challenged miceso, whereas administration of recombinant human ACE2 ameliorates H5N1 virus-induced lung injury in mice 30 . Importantly, ACE2 is currently at the center of a heated debate among cardiologists $31-34$, and there are concerns that medical management of hypertension, including the use of inhibitors of the reninangiotensin-aldosterone system (RAAS), may contribute to the adverse health outcomes

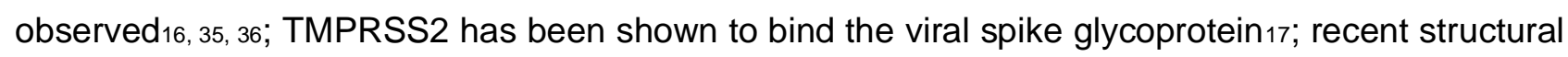


assays have suggested that coronaviruses can bind sialic acid receptors18; CD147 has been shown to be essential for the entry of cytomegalovirus into ECs24.

Endothelial dysfunction refers to a systemic condition in which the endothelium loses its physiological properties, including the tendency to promote vasodilation, fibrinolysis, and antiaggregation; moreover, endothelial dysfunction appears to be a consistent finding in patients with diabetes37. Here we will discuss clinical and preclinical findings supporting our hypothesis that COVID-19 impairs endothelial function (Figure 2).

\section{Hypertension and COVID-19}

Several investigators have called attention to the potential over-representation of hypertension among patients with COVID-1938, 39. Moreover, hypertension appears to track closely with advancing age, which is emerging as one of the strongest predictors of COVID-19-related death8, 40. Specifically, observational trials and retrospectives studies conducted near Wuhan area have actually shown that hypertension is the most common co-morbidity observed in patients affected by COVID-19, ranging from $15 \%$ to $31.2 \% 8,41-44$. The largest study has been conducted by Guan and colleagues between December 11, 2019, and January 29, 2020, providing data on 1099 hospitalized patients and outpatients with laboratory-confirmed COVID-19 infection 41 ; in this cohort, 165 of them ( 15\%) had high blood pressure 41 . The authors also evaluated the severity of disease, and the composite outcome of intensive care unit (ICU) admission, mechanical ventilation and death, concluding that $23.7 \%$ of hypertensive patients had disease severity (vs $13.4 \%$ of normotensive subjects), and that $35.8 \%$ (vs 13.7\%) reached the composite endpoint of ICU admission, mechanical ventilation and death 41 . The high rate of hypertensive patients in COVID-19 was later confirmed in a prospective analysis on 41 patients admitted to hospital in Wuhan 42 as well as in a large study conducted on 138 hospitalized patients with confirmed COVID-19 infection 43 . Notably, in the latter report, the rate of hypertension was $31.2 \%$, and $58.3 \%$ of hypertensive patients with COVID-19 infection were admitted to ICU compared to $21.6 \%$ of individuals with normal blood pressure 43 ; evidencing the hypertensive state as a common co- 
morbidity and cause of ICU admission in COVID-19 patients43. Similarly, among 191 COVID-19 patients from Jinyintan Hospital and Wuhan Pulmonary Hospital, 58 (30\%) of them had hypertension, and 26 of them (48\%) did not survive COVID-19, whereas 32 (23\%) were survivors8. Finally, the $30 \%$ rate of hypertensive patients was further confirmed in an analysis based on the severity of COVID-19 conducted on 140 patients in Wuhan: 58 patients were classified as severe vs 82 patients classified as no severe: hypertensive patients represented $37.9 \%$ of severe vs $24.4 \%$ of no severe COVID-19 patients 44 . Overall, these findings confirm a dual aspect of hypertension during COVID-19 pandemic: first, hypertension is the most common co-morbidity observed in COVID-19 patients; second, hypertension is evidenced in patients with worse prognosis and higher rate of death.

These studies also raise numerous questions regarding the association between hypertension and COVID-19. Indeed, it is well known that hypertension is one of most common disease and comorbidity worldwide, considered a silent killer for worldwide population 45 . We speculate that the higher rate of hypertension and the worse prognosis in patients with COVID-19 infection could be seen as the spy of a cause-effect mechanism more than of a casual pre-existing association between these two different diseases.

Recent reports evidenced higher morbidity and mortality rates of COVID-19 in African-Americans compared to Caucasian subjects in United States46. Of note, several studies have shown a higher prevalence of hypertension in blacks than in whites47, and ACE inhibitors (ACEi) and angiotensin II receptor blockers (ARS) have not been shown to be as effective in black populations compared with white populations 48 .

\section{ACE2 and anti-hypertensive drugs: what do we know?}

ACEi and ARS represent very effective strategies for the treatment of hypertension45. These drugs reduce the effects of renin-angiotensin axis by inhibiting ACE (ACEi) or by blocking the angiotensin receptors (ARS). A rising question for the scientific community and physicians is to understand whether ACEi/ARS could affect the prognosis of hypertensive COVID-19 patients16, 49, 50. 
Unfortunately, there are no data regarding specific anti-hypertensive medications and hypertensive COVID-19 patients with infection.

The role of ACEi/ARS in the control of ACE2 molecular pathways is controversial: indeed, preclinical studies evidenced that the selective blockade of either angiotensin II synthesis or activity in rats induces increases in ACE2 gene expression and activity51-54; similarly, treating infarcted rats with ARBs increased plasma concentration of angiotensin 1-7 and ACE255. In mice, ARB treatment augmented ACE2 mRNA and protein levels56, 57 and prevented the decrease in ACE2 protein levels induced by Angiotensin II $_{58}$. Equally important, mineralocorticoid receptor blockers prevented aldosterone induced reduction in cardiac ACE2 mRNA expression in rat cardiomyocytes59 and increased ACE2 expression and activity in murine hearts and in monocytederived macrophages obtained from 10 patients with heart failure60.

Nevertheless, there is no clinical evidence that ACEi directly affect molecular pathways linked to ACE2 activity. For instance, urinary ACE2 levels were reported to be higher in patients treated with olmesartan vs untreated controls, but this finding was not observed in patients treated with other ARS or enalapril61; instead, another study reported no difference in ACE2 activity in patients who were taking ACEi or ARS vs untreated patients49. Of note, clinically prescribed ACEls have been shown to not inhibit ACE2, which function as a carboxypeptidase62. In particular, ACE2 acts to counterbalance the effect of $\mathrm{ACE}_{63}$ : indeed, whereas ACE generates angiotensin II from angiotensin I, ACE2 converts angiotensin II into an active heptapeptide (angiotensin 1-7) with vasodilative, anti-oxidant, and anti-inflammatory properties64-66.

Some media sources have recently called for the discontinuation of ACE inhibitors and angiotensin-receptor blockers (ARBs), both prophylactically and in the context of suspected COVID-1967. Given the common use of ACE inhibitors and ARBs worldwide, guidance based on experimental evidence on the use of these drugs in patients with COVID-19 is urgently needed. Notably, there is no evidence regarding the effects of ACEi/ARS on circulating ACE2 expression and/or lung-specific expression of ACE2 during COVID-19 infection. Therefore, we can only speculate that human ACE2 expression can vary, and it could be altered by hypertension and/or by other pathological conditions as during COVID-19 infection. On the other hand, even assuming that 
ACEi/ARS could modify ACE2 levels and/or activity in humans, current studies cannot indicate if these effects could favor an enhanced engagement and/or entry of COVID-19 in humans.

The binding of the SARS-CoV-2 spike protein to ACE2 has been suggested to cause the downregulation of ACE2 from the cell membrane68. Consequently, ACE2 down-regulation could lead to a loss of protective effects exerted by ACEi/ARS in humans69. Such down-regulation of ACE2 is an attractive research field 54,70 . Indeed, it could be a valid therapeutic target to ameliorate response and clinical prognosis in hypertensive patients affected by COVID-19. Moreover, some investigators proposed the restoration of ACE2 by administration of recombinant ACE2 to reverse the lung-injury process during viral infections2. Actually, these effects are being investigated in ongoing clinical trials (ClinicalTrials.gov NCT04287686), alongside the use of losartan as first therapy for COVID-19 in hospitalized (NCT04312009) or not hospitalized patients (NCT04311177). A major role in the pathogenesis of (as well as in the clinical response to) COVID-19 could be also played by ACE2 polymorphisms, which are relatively under-investigated if compared to $A C E_{71,72 .}$

Finally, we have to consider the higher rate of cardiac injury and adverse outcomes in hypertensive patients during COVID-19 pandemic48, 73, 74. Therefore, ACEi/ARS chronic therapy should not be discontinued in hypertensive patients with COVID-19. Indeed, the loss of their pneumo- and cardioprotective effects could be detrimental 45 . In addition, in absence of adequate follow-up visits, switching from ACEi/ARS to another anti-hypertensive therapy could cause a suboptimal control of blood pressure. Thus, as suggested by several medical associations67, in absence of definitive clinical studies and without clear evidence, hypertensive patients should avoid discontinuation and/or therapeutic switching during COVID-19 infection.

\section{Diabetes and COVID-19}

Diabetes mellitus is a frequent co-morbidity and a cause of worse prognosis in patients with COVID-19 infection75-77. Indeed, evaluating pneumonia cases of unknown causes reported in Wuhan and in patients with history of exposure to Huanan seafood market before Jan 1, 2020, 
20\% had diabetes42. Similarly, among 1099 COVID-19 patients analyzed by Guan and colleagues, $7.4 \%$ had diabetes: this percentage goes up to $16.2 \%$ among patients with severe disease ( $v s$ $5.7 \%$ in patients with non-severe disease) 41 ; furthermore, $35.8 \%$ of patients experiencing the composite endpoint of ICU admission, mechanical ventilation and death, had diabetes (vs $13.7 \%$ of patients that did not experience such endpoint) 41 . In summary, diabetes is a frequent co-morbidity, a risk factor, and an independent prognostic factor in COVID-19 patients. A strong evidence of the negative effects of diabetes in COVID-19 patients is confirmed by two meta-analyses78, 79.

The worse prognosis in patients with diabetes and COVID-19 could be attributable to the fact that the pneumonia evolves towards clinical stages more refractory to medical therapies, oxygen administration and mechanical ventilation, with necessity of ICU care. These data have been investigated in a previous study conducted in patients with SARS 80 , in which the relationship between a known history of diabetes and fasting plasma glucose (FPG) levels with death and morbidity rate was assessed, showing that the percentage of patients with diabetes was significantly higher in deceased vs survivors $(21.5 \%$ vs $3.9 \%, \mathrm{P}<0.01) 80$. Moreover, diabetics with hypoxemia $\left(\mathrm{SaO}_{2}<93 \%\right)$ had higher FPG levels and FPG was independently associated with an increased hazard ratio of mortality $(1.1,95 \% \mathrm{Cl}: 1.0-1.1)$ and hypoxia $(1.1,95 \% \mathrm{Cl}: 1.0-1.1)$ after controlling for age and gender80. The authors concluded that diabetes (3.0, 95\% Cl: 1.4-6.3) and $\mathrm{FPG}>$ or $=7.0 \mathrm{mmol} / \mathrm{l}(3.3,95 \% \mathrm{Cl}: 1.4-7.7)$ were independent predictors of death 80 .

In COVID-19 patients, the incidence of diabetes is two-folds higher in ICU/severe vs nonICU/severe cases79. Indeed, the diagnosis of diabetes in a cohort of patients with COVID-19 Infection evidenced a sub-group of patients with a 2.26 -fold higher risk to experience adverse disease outcome analyses78. Unfortunately, no data are available on anti-diabetic medications and glucose homeostasis in COVID-19 patients. This aspect is really limiting, because the diagnosis of diabetes diagnosis and the altered glucose homeostasis during a condition of severe pneumonia with SARS are reported as main factors of worse prognosis and deaths 80 . Therefore, the investigation of anti-diabetic medications and glucose homeostasis could be harnessed to evaluate patients with higher risk to experience worse prognosis and death by COVID-19. We speculate that 
the amelioration of glucose homeostasis in diabetic COVID-19 patients by specific hypoglycemic drugs could result in the amelioration of clinical outcomes with death reduction. However, these data are not reported in trials on COVID-19, and they need to be investigated in further studies.

\section{Thrombosis and COVID-19}

Patients with COVID19 often show clotting disorders, with organ dysfunction and coagulopathy, resulting in higher mortality 81 . Important data came from the analysis of coagulation tests including prothrombin time (PT), activated partial thromboplastin time (APTT), antithrombin activity (AT), fibrinogen, fibrin degradation product (FDP), and D-dimer, in samples collected on admission and during the hospital stay of COVID-19 patients82. Non-survivors patients had significantly higher Ddimer and FDP levels, and longer PT vs survivors on admission82. Moreover, significant reduction and lowering of fibrinogen and AT levels were observed in non-survivors during late stages of hospitalization, which is compatible with a clinical diagnosis of disseminated intravascular coagulation (DIC) 82 . Hence, COVID-19 patients develop DIC, especially during the late stages83. Specifically, among 191 COVID-19 patients seen at two hospitals in Wuhan, D-dimer levels over 1 $\mu \mathrm{g} / \mathrm{L}$ at admission predicted an 18-fold increase in odds of dying before discharges. Of note, when DIC is caused by a systemic infection, it features an acute systemic over-inflammatory response, strictly linked to endothelial dysfunction 84 .

A dysregulated immune response, as seen in COVID-19, especially in the late stages of the disease, is known to play a decisive role in endothelial dysfunction and thrombosis 85,86 , and microvascular permeability is crucial in viral infections 87 . Indeed, pulmonary endothelium represent a fundamental barrier between the blood and interstitium and has vital regulatory functions; specifically, ECs represent $1 / 3$ of the cell population of the lungs8, and pulmonary endothelial damage is considered the hallmark of acute respiratory distress syndrome (ARDS) 89 . Animal models of coronavirus-induced severe ARDS have shown that reduced ACE2 activity and loss of ACE2 in the lungs is mirrored by enhanced vascular permeability, and exacerbated pulmonary edema66. Acute pulmonary embolism (APE), reported in COVID-19 patients90, 91, has been shown to be a cause of clinical deterioration in viral pneumonias92, 93. Intriguingly, endothelial dysfunction 
is known to be a key determinant in hypertension, thrombosis, and DIC $94-98$. A retrospective analysis evaluated 25 patients with COVID-19 pneumonia, who had a median of D-dimer of 6.06 $\mu \mathrm{g} / \mathrm{ml}$ and underwent computed tomography pulmonary angiography (CTPA) to detect APE9. From this analysis, 10 patients had APE confirmed by CTPA. APE was mainly found in small branches of the pulmonary artery, and in 3 patients there was partial or complete thrombus absorption after anticoagulant therapy. Henceforth, it is important to select COVID-19 patients at higher risk of APE, and practice CTPA for APE diagnosis especially in case of significant increase of D-dimer values. Anticoagulation could be a necessary therapy to control and reduce pro-thrombotic events, as well as to prevent APE99.

\section{Anticoagulation as a therapy for COVID-19.}

As discussed before, COVID-19 infection could cause endothelial dysfunction and a hypercoagulation state. This condition is aggravated by hypoxia, which augments thrombosis by both increasing blood viscosity and hypoxia-inducible transcription factor-dependent signaling pathway100. Consequently, these phenomena could result in APE with occlusion and microthrombosis in pulmonary small vessels, as observed in critical COVID-19 patients101. Apart from cases of APE, COVID-19 can cause a sepsis-associated DIC, that is defined "sepsis-induced coagulopathy" (SIC) 84 . Thus, there is an increasing interest for the anticoagulant therapy for COVID-19. In a retrospective analysis conducted at Tongji Hospital of Huazhong University of Science and Technology in Wuhan, the authors examined 449 patients affected by severe COVID1999. The diagnosis of severe COVID-19 disease was made by evidence of respiratory rate $\geq 30$ breaths/min, arterial oxygen saturation $\leq 93 \%$ at rest and $\mathrm{PaO}_{2} / \mathrm{FiO}_{2} \leq 300 \mathrm{mmHg} 99$. In these patients, they reviewed and compared the parameters of coagulation tests and clinical characteristics between survivors and non-survivors to evaluate the effects of heparin therapy99: 94 patients received low molecular weight heparin (LMWH, 40-60 mg enoxaparin/day) and 5 received unfractioned heparin (UFH, 10000-15000 U/day), without other anticoagulants99. Heparin therapy significantly reduced mortality in patients with SIC score $\geq 4(40.0 \%$ vs $64.2 \%, p<0.05)$, but not in those with SIC score $<4(29.0 \%$ vs $22.6 \%$, p>0.05) 99 . D-dimer, PT, and age were positively, while 
platelet count was negatively correlated with 28-day mortality99. In addition, stratifying by D-dimer values the study population, the authors reported in heparin nonusers a rise of mortality linked to the rising D-dimer, and $20 \%$ reduction of mortality for patients under heparin with D-dimer exceeding $3.0 \mu \mathrm{g} / \mathrm{mL}$ 99. Therefore, heparin treatment appears to be associated with better prognosis in severe COVID-19 patients with coagulopathy. The full clinical evaluation of patients with COVID-19 infection cannot leave aside from the analysis of laboratory and imaging data. We believe that PT/PTT, fibrinogen, and D-Dimer should be monitored daily and anticoagulation therapy should be recommended for COVID-19 patients when the D-Dimer value is 4 times higher than the normal upper limit, except for patients with anticoagulant contraindications. The confirmed diagnosis of severe COVID-19 disease in patients with hypercoagulation and organ failure could evidence an early stage of sepsis-induced DIC. On the other hand, anticoagulant may not benefit unselected patients. Consequently, further prospective studies are needed to confirm this result in COVID-19 patients, also testing other antiaggregants and anticoagulants (at different doses), including novel direct oral anticoagulants (NOAC or DOAC).

\section{Other therapeutic approaches}

Recently, chloroquine and hydroxychloroquine have been suggested as a potential therapy for COVID-19102, 103, although the exact molecular mechanisms remain unknown; if our hypothesis on the key role of ECs in COVID-19 disease is confirmed, these drugs may exert their beneficial effects via an amelioration of endothelial dysfunction. Indeed, consistent with our view, both these antimalaric agents have been shown to improve endothelial function 104,105 and to alter the glycosylation profiles of ACE2 by increasing the $\mathrm{pH}$ of intracellular organelles, including lysosomes and Golgi 106. Strikingly, similar findings have been reported for colchicine107, azithromycin 108, and tocilizumab 109 , recently proposed as treatment for COVID-19102, 110.

Funding: The Santulli's lab is supported in part by the NIH (R01-HL146691, R01-DK033823, R01DK123259, P30-DK020541, and R00-DK107895 to G.S.) and by the American Heart Association (AHA-20POST35211151 to J.G.). 
Conflict of interests: none. 


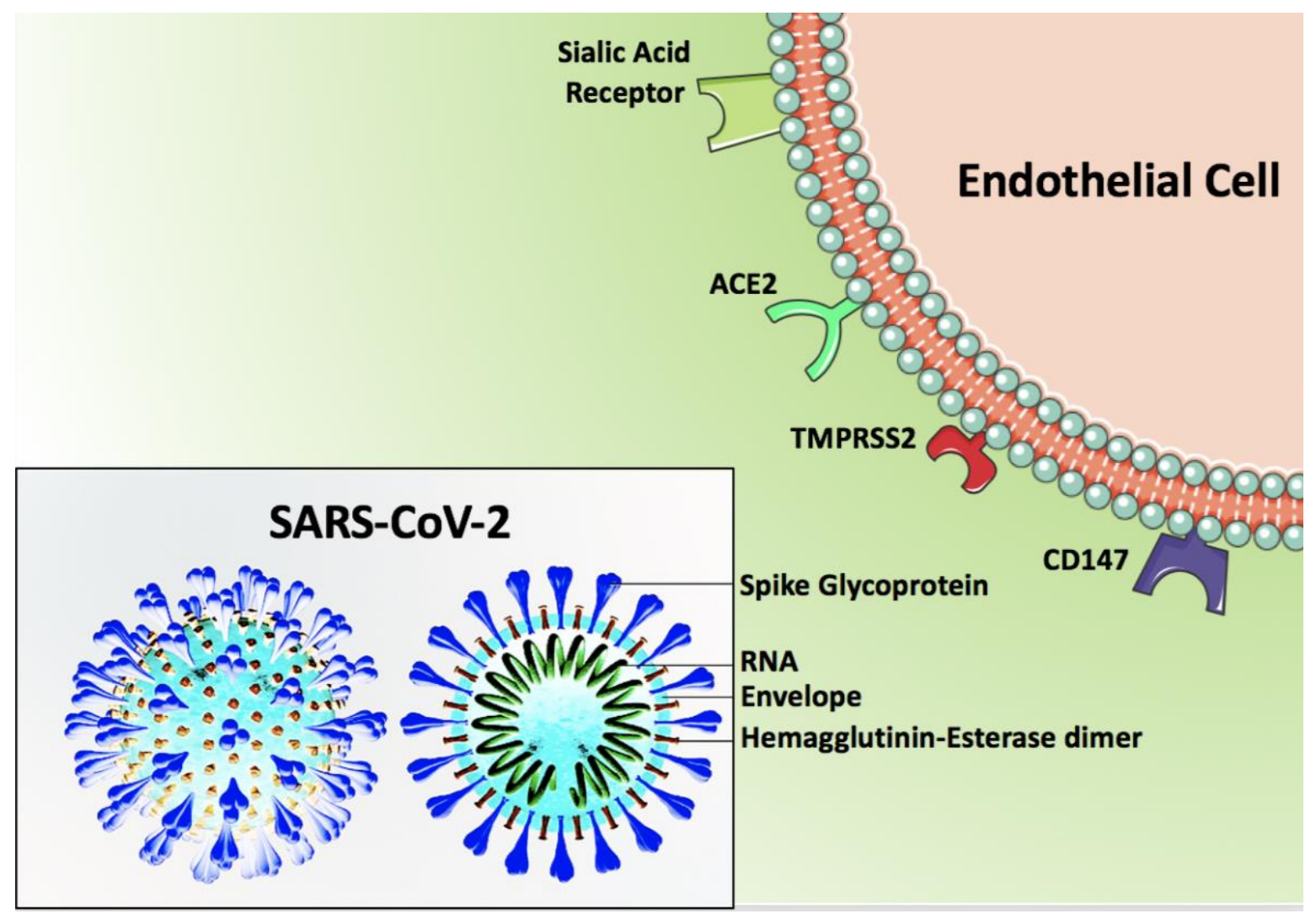

Figure 1.

Pathogenesis of COVID-19.

The SARS-CoV-2 coronavirus accesses host cells via the binding of its spike glycoprotein to angiotensin-converting enzyme 2 (ACE2), sialic acid receptor, transmembrane serine protease 2 (TMPRSS2), and extracellular matrix metalloproteinase inducer (CD147). 


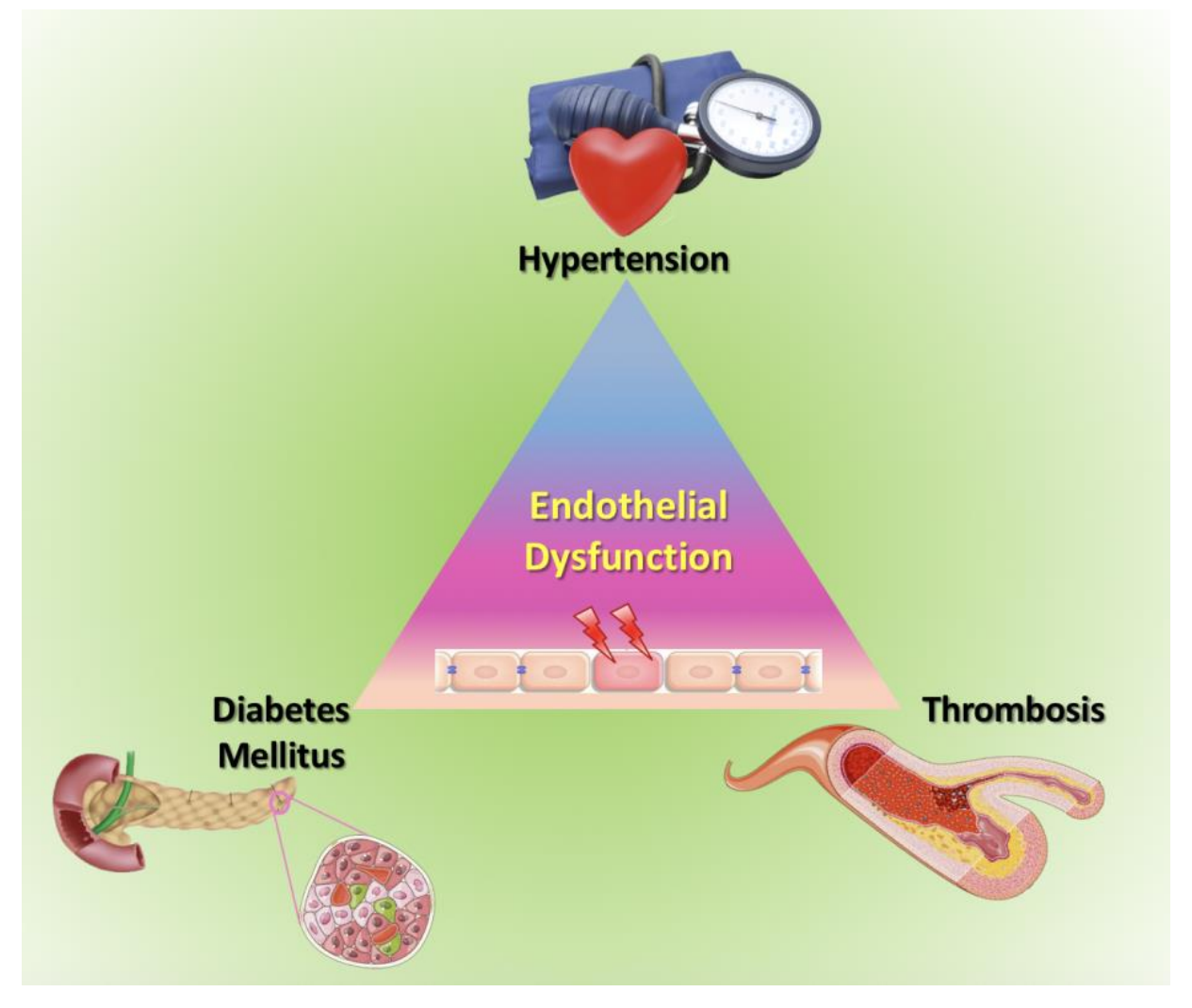

\section{Figure 2.}

Endothelial dysfunction is a major determinant of COVID-19.

Endothelial dysfunction is a common feature of hypertension, diabetes, and thrombosis, critical clinical findings in COVID-19 patients. 


\section{References}

1. Hui DS, E IA, Madani TA, Ntoumi F, Kock R, Dar O, Ippolito G, McHugh TD, Memish ZA, Drosten C, Zumla A and Petersen E. The continuing 2019-nCoV epidemic threat of novel coronaviruses to global health - The latest 2019 novel coronavirus outbreak in Wuhan, China. Int $J$ Infect Dis. 2020;91:264-266.

2. Zhang $\mathrm{H}$, Penninger JM, Li Y, Zhong $\mathrm{N}$ and Slutsky AS. Angiotensin-converting enzyme 2 (ACE2) as a SARS-CoV-2 receptor: molecular mechanisms and potential therapeutic target. Intensive Care Med. 2020;46:586-590.

3. Zhou P, Yang XL, Wang XG, Hu B, Zhang L, Zhang W, Si HR, Zhu Y, Li B, Huang CL, Chen HD, Chen J, Luo Y, Guo H, Jiang RD, Liu MQ, Chen Y, Shen XR, Wang X, Zheng XS, Zhao K, Chen QJ, Deng F, Liu LL, Yan B, Zhan FX, Wang YY, Xiao GF and Shi ZL. A pneumonia outbreak associated with a new coronavirus of probable bat origin. Nature. 2020;579:270-273.

4. Hamming I, Timens W, Bulthuis ML, Lely AT, Navis G and van Goor H. Tissue distribution of ACE2 protein, the functional receptor for SARS coronavirus. A first step in understanding SARS pathogenesis. J Pathol. 2004;203:631-7.

5. Lovren F, Pan Y, Quan A, Teoh H, Wang G, Shukla PC, Levitt KS, Oudit GY, AI-Omran M, Stewart DJ, Slutsky AS, Peterson MD, Backx PH, Penninger JM and Verma S. Angiotensin converting enzyme-2 confers endothelial protection and attenuates atherosclerosis. Am J Physiol Heart Circ Physiol. 2008;295:H1377-84.

6. Sluimer JC, Gasc JM, Hamming I, van Goor H, Michaud A, van den Akker LH, Jutten B, Cleutjens J, Bijnens AP, Corvol P, Daemen MJ and Heeneman S. Angiotensin-converting enzyme 2 (ACE2) expression and activity in human carotid atherosclerotic lesions. J Pathol. 2008;215:2739.

7. Schiffrin EL, Flack J, Ito S, Muntner P and Webb C. Hypertension and COVID-19. Am J Hypertens. 2020.

8. Zhou F, Yu T, Du R, Fan G, Liu Y, Liu Z, Xiang J, Wang Y, Song B, Gu X, Guan L, Wei Y, Li H, Wu X, Xu J, Tu S, Zhang Y, Chen H and Cao B. Clinical course and risk factors for mortality 
of adult inpatients with COVID-19 in Wuhan, China: a retrospective cohort study. Lancet. 2020;395:1054-1062.

9. Chen J, Wang X, Zhang S, Liu B, Wu X, Wang Y, Wang X, Yang M, Sun J and Xie Y. Findings of Acute Pulmonary Embolism in COVID-19 Patients. Lancet. 2020.

10. Cooke JP. The endothelium: a new target for therapy. Vasc Med. 2000;5:49-53.

11. Letko M, Marzi A and Munster V. Functional assessment of cell entry and receptor usage for SARS-CoV-2 and other lineage B betacoronaviruses. Nat Microbiol. 2020;5:562-569.

12. Wang Q, Zhang Y, Wu L, Niu S, Song C, Zhang Z, Lu G, Qiao C, Hu Y, Yuen KY, Wang Q, Zhou H, Yan J and Qi J. Structural and Functional Basis of SARS-CoV-2 Entry by Using Human ACE2. Cell. 2020.

13. Xu H, Zhong L, Deng J, Peng J, Dan H, Zeng X, Li T and Chen Q. High expression of ACE2 receptor of 2019-nCoV on the epithelial cells of oral mucosa. Int J Oral Sci. 2020;12:8.

14. Jia HP, Look DC, Shi L, Hickey M, Pewe L, Netland J, Farzan M, Wohlford-Lenane C, Perlman S and McCray PB, Jr. ACE2 receptor expression and severe acute respiratory syndrome coronavirus infection depend on differentiation of human airway epithelia. J Virol. 2005;79:1461421.

15. Perico L, Benigni A and Remuzzi G. Should COVID-19 Concern Nephrologists? Why and to What Extent? The Emerging Impasse of Angiotensin Blockade. Nephron. 2020:1-9.

16. Gheblawi M, Wang K, Viveiros A, Nguyen Q, Zhong J, Turner AT, Raizada MK, Grant MB and Oudit GY. Angiotensin Converting Enzyme 2: SARS-CoV-2 Receptor and Regulator of the Renin-Angiotensin System. Circ Res. 2020.

17. Matsuyama S, Nao N, Shirato K, Kawase M, Saito S, Takayama I, Nagata N, Sekizuka T, Katoh H, Kato F, Sakata M, Tahara M, Kutsuna S, Ohmagari N, Kuroda M, Suzuki T, Kageyama T and Takeda M. Enhanced isolation of SARS-CoV-2 by TMPRSS2-expressing cells. Proc Natl Acad Sci U S A. 2020;117:7001-7003.

18. Tortorici MA, Walls AC, Lang Y, Wang C, Li Z, Koerhuis D, Boons GJ, Bosch BJ, Rey FA, de Groot RJ and Veesler D. Structural basis for human coronavirus attachment to sialic acid receptors. Nat Struct Mol Biol. 2019;26:481-489. 
19. Hulswit RJG, Lang Y, Bakkers MJG, Li W, Li Z, Schouten A, Ophorst B, van Kuppeveld FJM, Boons GJ, Bosch BJ, Huizinga EG and de Groot RJ. Human coronaviruses OC43 and HKU1 bind to 9-O-acetylated sialic acids via a conserved receptor-binding site in spike protein domain A. Proc Natl Acad Sci U S A. 2019;116:2681-2690.

20. Chen Z, Mi L, Xu J, Yu J, Wang X, Jiang J, Xing J, Shang P, Qian A, Li Y, Shaw PX, Wang J, Duan S, Ding J, Fan C, Zhang Y, Yang Y, Yu X, Feng Q, Li B, Yao X, Zhang Z, Li L, Xue X and Zhu P. Function of HAb18G/CD147 in invasion of host cells by severe acute respiratory syndrome coronavirus. J Infect Dis. 2005;191:755-60.

21. Yang J, Feng X, Zhou Q, Cheng W, Shang C, Han P, Lin CH, Chen HS, Quertermous T and Chang CP. Pathological Ace2-to-Ace enzyme switch in the stressed heart is transcriptionally controlled by the endothelial Brg1-FoxM1 complex. Proc Natl Acad Sci U S A. 2016;113:E5628-35.

22. Aimes RT, Zijlstra A, Hooper JD, Ogbourne SM, Sit ML, Fuchs S, Gotley DC, Quigley JP and Antalis TM. Endothelial cell serine proteases expressed during vascular morphogenesis and angiogenesis. Thromb Haemost. 2003;89:561-72.

23. Huang DT, Lu CY, Chi YH, Li WL, Chang LY, Lai MJ, Chen JS, Hsu WM and Huang LM. Adaptation of influenza A (H7N9) virus in primary human airway epithelial cells. Sci Rep. $2017 ; 7: 11300$.

24. Vanarsdall AL, Pritchard SR, Wisner TW, Liu J, Jardetzky TS and Johnson DC. CD147 Promotes Entry of Pentamer-Expressing Human Cytomegalovirus into Epithelial and Endothelial Cells. mBio. 2018;9.

25. Rivellese F and Prediletto E. ACE2 at the centre of COVID-19 from paucisymptomatic infections to severe pneumonia. Autoimmun Rev. 2020:102536.

26. Touyz RM, Li H and Delles C. ACE2 the Janus-faced protein - from cardiovascular protection to severe acute respiratory syndrome-coronavirus and COVID-19. Clin Sci (Lond). 2020;134:747-750.

27. Leng Z, Zhu R, Hou W, Feng Y, Yang Y, Han Q, Shan G, Meng F, Du D, Wang S, Fan J, Wang W, Deng L, Shi H, Li H, Hu Z, Zhang F, Gao J, Liu H, Li X, Zhao Y, Yin K, He X, Gao Z, Wang Y, Yang B, Jin R, Stambler I, Lim LW, Su H, Moskalev A, Cano A, Chakrabarti S, Min KJ, 
Ellison-Hughes G, Caruso C, Jin K and Zhao RC. Transplantation of ACE2(-) Mesenchymal Stem Cells Improves the Outcome of Patients with COVID-19 Pneumonia. Aging Dis. 2020;11:216-228. 28. Brake SJ, Barnsley K, Lu W, McAlinden KD, Eapen MS and Sohal SS. Smoking Upregulates Angiotensin-Converting Enzyme-2 Receptor: A Potential Adhesion Site for Novel Coronavirus SARS-CoV-2 (Covid-19). J Clin Med. 2020;9.

29. Jakovac H. COVID-19 - is the ACE2 just a foe? Am J Physiol Lung Cell Mol Physiol. 2020.

30. Zou Z, Yan Y, Shu Y, Gao R, Sun Y, Li X, Ju X, Liang Z, Liu Q, Zhao Y, Guo F, Bai T, Han Z, Zhu J, Zhou H, Huang F, Li C, Lu H, Li N, Li D, Jin N, Penninger JM and Jiang C. Angiotensinconverting enzyme 2 protects from lethal avian influenza A H5N1 infections. Nat Commun. 2014;5:3594.

31. Guo J, Huang Z, Lin L and Lv J. Coronavirus Disease 2019 (COVID-19) and Cardiovascular Disease: A Viewpoint on the Potential Influence of Angiotensin-Converting Enzyme Inhibitors/Angiotensin Receptor Blockers on Onset and Severity of Severe Acute Respiratory Syndrome Coronavirus 2 Infection. J Am Heart Assoc. 2020;9:e016219.

32. Mourad JJ and Levy BI. Interaction between RAAS inhibitors and ACE2 in the context of COVID-19. Nat Rev Cardiol. 2020.

33. South AM, Diz D and Chappell MC. COVID-19, ACE2 and the Cardiovascular Consequences. Am J Physiol Heart Circ Physiol. 2020.

34. Chen L, Li X, Chen M, Feng Y and Xiong C. The ACE2 expression in human heart indicates new potential mechanism of heart injury among patients infected with SARS-CoV-2. Cardiovasc Res. 2020.

35. Sommerstein R, Kochen MM, Messerli FH and Grani C. Coronavirus Disease 2019 (COVID-19): Do Angiotensin-Converting Enzyme Inhibitors/Angiotensin Receptor Blockers Have a Biphasic Effect? J Am Heart Assoc. 2020;9:e016509.

36. Danser AHJ, Epstein M and Batlle D. Renin-Angiotensin System Blockers and the COVID19 Pandemic: At Present There Is No Evidence to Abandon Renin-Angiotensin System Blockers. Hypertension. 2020:HYPERTENSIONAHA12015082. 
37. Avogaro A, Albiero M, Menegazzo L, de Kreutzenberg S and Fadini GP. Endothelial dysfunction in diabetes: the role of reparatory mechanisms. Diabetes Care. 2011;34 Suppl 2:S28590.

38. Esler M and Esler D. Can angiotensin receptor-blocking drugs perhaps be harmful in the COVID-19 pandemic? J Hypertens. 2020.

39. Fang L, Karakiulakis $G$ and Roth $M$. Are patients with hypertension and diabetes mellitus at increased risk for COVID-19 infection? Lancet Respir Med. 2020.

40. Wu J, Leung KSM, Bushman M, Kishore N, Niehus R, de Salazar P, Cowling BJ, Lipsitch M and Leung G. Estimating clinical severity of COVID-19 from the transmission dynamics in Wuhan, China. Nat Med. 2020.

41. Guan WJ, Ni ZY, Hu Y, Liang WH, Ou CQ, He JX, Liu L, Shan H, Lei CL, Hui DSC, Du B, Li LJ, Zeng G, Yuen KY, Chen RC, Tang CL, Wang T, Chen PY, Xiang J, Li SY, Wang JL, Liang ZJ, Peng YX, Wei L, Liu Y, Hu YH, Peng P, Wang JM, Liu JY, Chen Z, Li G, Zheng ZJ, Qiu SQ, Luo J, Ye CJ, Zhu SY, Zhong NS and China Medical Treatment Expert Group for C. Clinical Characteristics of Coronavirus Disease 2019 in China. N Engl J Med. 2020.

42. Huang C, Wang Y, Li X, Ren L, Zhao J, Hu Y, Zhang L, Fan G, Xu J, Gu X, Cheng Z, Yu T, Xia J, Wei Y, Wu W, Xie X, Yin W, Li H, Liu M, Xiao Y, Gao H, Guo L, Xie J, Wang G, Jiang R, Gao Z, Jin Q, Wang J and Cao B. Clinical features of patients infected with 2019 novel coronavirus in Wuhan, China. Lancet. 2020;395:497-506.

43. Wang D, Hu B, Hu C, Zhu F, Liu X, Zhang J, Wang B, Xiang H, Cheng Z, Xiong Y, Zhao Y, Li Y, Wang X and Peng Z. Clinical Characteristics of 138 Hospitalized Patients With 2019 Novel Coronavirus-Infected Pneumonia in Wuhan, China. JAMA. 2020.

44. Zhang JJ, Dong X, Cao YY, Yuan YD, Yang YB, Yan YQ, Akdis CA and Gao YD. Clinical characteristics of 140 patients infected with SARS-CoV-2 in Wuhan, China. Allergy. 2020.

45. Williams B, Mancia G, Spiering W, Agabiti Rosei E, Azizi M, Burnier M, Clement DL, Coca A, de Simone G, Dominiczak A, Kahan T, Mahfoud F, Redon J, Ruilope L, Zanchetti A, Kerins M, Kjeldsen SE, Kreutz R, Laurent S, Lip GYH, McManus R, Narkiewicz K, Ruschitzka F, Schmieder 
RE, Shlyakhto E, Tsioufis C, Aboyans V, Desormais I and Group ESCSD. 2018 ESC/ESH Guidelines for the management of arterial hypertension. Eur Heart J. 2018;39:3021-3104.

46. Garg S, Kim L, Whitaker M, O’Halloran A, Cummings C, Holstein R, Prill M, Chai S, Kirley P and Alden NB. Hospitalization Rates and Characteristics of Patients Hospitalized with LaboratoryConfirmed Coronavirus Disease 2019 - COVID-NET, 14 States, March 1-30, 2020. MMWR Morb Mortal Wkly Rep. 2020.

47. Fuchs FD. Why do black Americans have higher prevalence of hypertension?: an enigma still unsolved. Hypertension. 2011;57:379-80.

48. Lackland DT. Racial differences in hypertension: implications for high blood pressure management. Am J Med Sci. 2014;348:135-8.

49. Vaduganathan M, Vardeny O, Michel T, McMurray JJV, Pfeffer MA and Solomon SD. Renin-Angiotensin-Aldosterone System Inhibitors in Patients with Covid-19. N Engl J Med. 2020.

50. Gurwitz D. Angiotensin receptor blockers as tentative SARS-CoV-2 therapeutics. Drug Dev Res. 2020.

51. Ferrario CM, Jessup J, Chappell MC, Averill DB, Brosnihan KB, Tallant EA, Diz DI and Gallagher PE. Effect of angiotensin-converting enzyme inhibition and angiotensin II receptor blockers on cardiac angiotensin-converting enzyme 2. Circulation. 2005;111:2605-10.

52. Jessup JA, Gallagher PE, Averill DB, Brosnihan KB, Tallant EA, Chappell MC and Ferrario $\mathrm{CM}$. Effect of angiotensin II blockade on a new congenic model of hypertension derived from transgenic Ren-2 rats. Am J Physiol Heart Circ Physiol. 2006;291:H2166-72.

53. Igase M, Strawn WB, Gallagher PE, Geary RL and Ferrario CM. Angiotensin II AT1 receptors regulate ACE2 and angiotensin-(1-7) expression in the aorta of spontaneously hypertensive rats. Am J Physiol Heart Circ Physiol. 2005;289:H1013-9.

54. South AM, Tomlinson L, Edmonston D, Hiremath S and Sparks MA. Controversies of reninangiotensin system inhibition during the COVID-19 pandemic. Nat Rev Nephrol. 2020.

55. Ishiyama $\mathrm{Y}$, Gallagher PE, Averill DB, Tallant EA, Brosnihan KB and Ferrario CM. Upregulation of angiotensin-converting enzyme 2 after myocardial infarction by blockade of angiotensin II receptors. Hypertension. 2004;43:970-6. 
56. Jin HY, Song B, Oudit GY, Davidge ST, Yu HM, Jiang YY, Gao PJ, Zhu DL, Ning G, Kassiri Z, Penninger JM and Zhong JC. ACE2 deficiency enhances angiotensin II-mediated aortic profilin1 expression, inflammation and peroxynitrite production. PLoS One. 2012;7:e38502.

57. Soler MJ, Ye M, Wysocki J, William J, Lloveras J and Batlle D. Localization of ACE2 in the renal vasculature: amplification by angiotensin II type 1 receptor blockade using telmisartan. $A m$ J Physiol Renal Physiol. 2009;296:F398-405.

58. Patel VB, Clarke N, Wang Z, Fan D, Parajuli N, Basu R, Putko B, Kassiri Z, Turner AJ and Oudit GY. Angiotensin II induced proteolytic cleavage of myocardial ACE2 is mediated by TACE/ADAM-17: a positive feedback mechanism in the RAS. J Mol Cell Cardiol. 2014;66:167-76.

59. Yamamuro M, Yoshimura M, Nakayama M, Abe K, Sumida H, Sugiyama S, Saito Y, Nakao $\mathrm{K}$, Yasue $\mathrm{H}$ and Ogawa $\mathrm{H}$. Aldosterone, but not angiotensin II, reduces angiotensin converting enzyme 2 gene expression levels in cultured neonatal rat cardiomyocytes. Circ J. 2008;72:134650.

60. Keidar S, Gamliel-Lazarovich A, Kaplan M, Pavlotzky E, Hamoud S, Hayek T, Karry R and Abassi Z. Mineralocorticoid receptor blocker increases angiotensin-converting enzyme 2 activity in congestive heart failure patients. Circ Res. 2005;97:946-53.

61. Furuhashi M, Moniwa N, Mita T, Fuseya T, Ishimura S, Ohno K, Shibata S, Tanaka M, Watanabe Y, Akasaka H, Ohnishi H, Yoshida H, Takizawa H, Saitoh S, Ura N, Shimamoto K and Miura T. Urinary angiotensin-converting enzyme 2 in hypertensive patients may be increased by olmesartan, an angiotensin II receptor blocker. Am J Hypertens. 2015;28:15-21.

62. Rice GI, Thomas DA, Grant PJ, Turner AJ and Hooper NM. Evaluation of angiotensinconverting enzyme (ACE), its homologue ACE2 and neprilysin in angiotensin peptide metabolism. Biochem J. 2004;383:45-51.

63. Nicholls $\mathrm{J}$ and Peiris M. Good ACE, bad ACE do battle in lung injury, SARS. Nat Med. $2005 ; 11: 821-2$.

64. Santos RA. Angiotensin-(1-7). Hypertension. 2014;63:1138-47. 
65. El-Hashim AZ, Renno WM, Raghupathy R, Abduo HT, Akhtar S and Benter IF. Angiotensin(1-7) inhibits allergic inflammation, via the MAS1 receptor, through suppression of ERK1/2- and NF-kappaB-dependent pathways. Br J Pharmacol. 2012;166:1964-76.

66. Kuba K, Imai Y, Rao S, Gao H, Guo F, Guan B, Huan Y, Yang P, Zhang Y, Deng W, Bao L, Zhang B, Liu G, Wang Z, Chappell M, Liu Y, Zheng D, Leibbrandt A, Wada T, Slutsky AS, Liu D, Qin C, Jiang C and Penninger JM. A crucial role of angiotensin converting enzyme 2 (ACE2) in SARS coronavirus-induced lung injury. Nat Med. 2005;11:875-9.

67. Patel $A B$ and Verma A. COVID-19 and Angiotensin-Converting Enzyme Inhibitors and Angiotensin Receptor Blockers: What Is the Evidence? JAMA. 2020.

68. Glowacka I, Bertram S, Herzog P, Pfefferle S, Steffen I, Muench MO, Simmons G, Hofmann H, Kuri T, Weber F, Eichler J, Drosten C and Pohlmann S. Differential downregulation of ACE2 by the spike proteins of severe acute respiratory syndrome coronavirus and human coronavirus NL63. J Virol. 2010;84:1198-205.

69. Luque M, Martin P, Martell N, Fernandez C, Brosnihan KB and Ferrario CM. Effects of captopril related to increased levels of prostacyclin and angiotensin-(1-7) in essential hypertension. J Hypertens. 1996;14:799-805.

70. Chen $L$ and Hao $G$. The role of angiotensin-converting enzyme 2 in coronaviruses/influenza viruses and cardiovascular disease. Cardiovasc Res. 2020.

71. Fan Z, Wu G, Yue M, Ye J, Chen Y, Xu B, Shu Z, Zhu J, Lu N and Tan X. Hypertension and hypertensive left ventricular hypertrophy are associated with ACE2 genetic polymorphism. Life Sci. 2019;225:39-45.

72. Pinheiro DS, Santos RS, Jardim P, Silva EG, Reis AAS, Pedrino GR and Ulhoa CJ. The combination of ACE I/D and ACE2 G8790A polymorphisms revels susceptibility to hypertension: A genetic association study in Brazilian patients. PLoS One. 2019;14:e0221248.

73. Bonow RO, Fonarow GC, O'Gara PT and Yancy CW. Association of Coronavirus Disease 2019 (COVID-19) With Myocardial Injury and Mortality. JAMA Cardiol. 2020. 
74. Guo T, Fan Y, Chen M, Wu X, Zhang L, He T, Wang H, Wan J, Wang X and Lu Z. Cardiovascular Implications of Fatal Outcomes of Patients With Coronavirus Disease 2019 (COVID-19). JAMA Cardiol. 2020.

75. Gentile S, Strollo F and Ceriello A. COVID-19 Infection in italian people with diabetes: lessons learned for our future (an experience to be used). Diabetes Res Clin Pract. 2020:108137. 76. Ma RCW and Holt RIG. COVID-19 and diabetes. Diabet Med. 2020.

77. Muniyappa R and Gubbi S. COVID-19 Pandemic, Corona Viruses, and Diabetes Mellitus. Am J Physiol Endocrinol Metab. 2020.

78. Fadini GP, Morieri ML, Longato E and Avogaro A. Prevalence and impact of diabetes among people infected with SARS-CoV-2. J Endocrinol Invest. 2020.

79. Li B, Yang J, Zhao F, Zhi L, Wang X, Liu L, Bi Z and Zhao Y. Prevalence and impact of cardiovascular metabolic diseases on COVID-19 in China. Clin Res Cardiol. 2020.

80. Yang JK, Feng Y, Yuan MY, Yuan SY, Fu HJ, Wu BY, Sun GZ, Yang GR, Zhang XL, Wang L, Xu X, Xu XP and Chan JC. Plasma glucose levels and diabetes are independent predictors for mortality and morbidity in patients with SARS. Diabet Med. 2006;23:623-8.

81. Zhang MD, Xiao M, Zhang S, Xia P, Caio W and Jiang W. Coagulopathy and Antiphospholipid Antibodies in Patients with Covid-19. NEJM. 2020.

82. Tang N, Li D, Wang $X$ and Sun Z. Abnormal coagulation parameters are associated with poor prognosis in patients with novel coronavirus pneumonia. J Thromb Haemost. 2020;18:844847.

83. Lin L, Lu L, Cao W and Li T. Hypothesis for potential pathogenesis of SARS-CoV-2 infection-a review of immune changes in patients with viral pneumonia. Emerg Microbes Infect. 2020;9:727-732.

84. Iba T, Levy JH, Warkentin TE, Thachil J, van der Poll T, Levi M, Scientific, Standardization Committee on DIC, the S, Standardization Committee on P, Critical Care of the International Society on T and Haemostasis. Diagnosis and management of sepsis-induced coagulopathy and disseminated intravascular coagulation. J Thromb Haemost. 2019;17:1989-1994. 
85. Schulz C, Engelmann B and Massberg S. Crossroads of coagulation and innate immunity: the case of deep vein thrombosis. J Thromb Haemost. 2013;11 Suppl 1:233-41.

86. Mezger M, Nording H, Sauter R, Graf T, Heim C, von Bubnoff N, Ensminger SM and Langer HF. Platelets and Immune Responses During Thromboinflammation. Front Immunol. 2019;10:1731.

87. Steinberg BE, Goldenberg NM and Lee WL. Do viral infections mimic bacterial sepsis? The role of microvascular permeability: A review of mechanisms and methods. Antiviral Res. 2012;93:2-15.

88. Zeng H, Pappas C, Belser JA, Houser KV, Zhong W, Wadford DA, Stevens T, Balczon R, Katz JM and Tumpey TM. Human pulmonary microvascular endothelial cells support productive replication of highly pathogenic avian influenza viruses: possible involvement in the pathogenesis of human H5N1 virus infection. J Virol. 2012;86:667-78.

89. Maniatis NA and Orfanos SE. The endothelium in acute lung injury/acute respiratory distress syndrome. Curr Opin Crit Care. 2008;14:22-30.

90. Xie $\mathrm{Y}$, Wang $\mathrm{X}$, Yang $\mathrm{P}$ and Shutong Z. COVID-19 complicated by acute pulmonary embolism. Radiology. 2020.

91. Danzi GB, Loffi M, Galeazzi G and Gherbesi E. Acute pulmonary embolism and COVID-19 pneumonia: a random association? Eur Heart J. 2020.

92. Jolobe OMP. Similarities Between Community-Acquired Pneumonia and Pulmonary Embolism. Am J Med. 2019;132:e863.

93. Ishiguro T, Matsuo K, Fujii $S$ and Takayanagi N. Acute thrombotic vascular events complicating influenza-associated pneumonia. Respir Med Case Rep. 2019;28:100884.

94. Santulli G. MicroRNAs and Endothelial (Dys) Function. J Cell Physiol. 2016;231:1638-44.

95. Santulli G. Endothelial cells: The heart attack of the Clones. Sci Trans/ Med. 2018;10.

96. Yuan Q, Yang J, Santulli G, Reiken SR, Wronska A, Kim MM, Osborne BW, Lacampagne A, Yin Y and Marks AR. Maintenance of normal blood pressure is dependent on IP3R1-mediated regulation of eNOS. Proc Natl Acad Sci U S A. 2016;113:8532-7. 
97. Gando $\mathrm{S}$, Levi $\mathrm{M}$ and Toh $\mathrm{CH}$. Disseminated intravascular coagulation. Nat Rev Dis Primers. 2016;2:16037.

98. Walborn A, Rondina M, Mosier M, Fareed J and Hoppensteadt D. Endothelial Dysfunction Is Associated with Mortality and Severity of Coagulopathy in Patients with Sepsis and Disseminated Intravascular Coagulation. Clin Appl Thromb Hemost. 2019;25:1076029619852163.

99. Tang N, Bai H, Chen X, Gong J, Li D and Sun Z. Anticoagulant treatment is associated with decreased mortality in severe coronavirus disease 2019 patients with coagulopathy. $J$ Thromb Haemost. 2020.

100. Gupta N, Zhao YY and Evans CE. The stimulation of thrombosis by hypoxia. Thromb Res. 2019;181:77-83.

101. Xu Z, Shi L, Wang Y, Zhang J, Huang L, Zhang C, Liu S, Zhao P, Liu H, Zhu L, Tai Y, Bai C, Gao T, Song J, Xia P, Dong J, Zhao J and Wang FS. Pathological findings of COVID-19 associated with acute respiratory distress syndrome. Lancet Respir Med. 2020;8:420-422.

102. Rubin EJ, Baden LR and Morrissey S. Audio Interview: New Research on Possible Treatments for Covid-19. N Engl J Med. 2020;382:e30.

103. Yazdany J and Kim AHJ. Use of Hydroxychloroquine and Chloroquine During the COVID19 Pandemic: What Every Clinician Should Know. Ann Intern Med. 2020.

104. Le NT, Takei Y, Izawa-Ishizawa Y, Heo KS, Lee H, Smrcka AV, Miller BL, Ko KA, Ture S, Morrell C, Fujiwara K, Akaike M and Abe J. Identification of activators of ERK5 transcriptional activity by high-throughput screening and the role of endothelial ERK5 in vasoprotective effects induced by statins and antimalarial agents. J Immunol. 2014;193:3803-15.

105. Rahman R, Murthi P, Singh H, Gurusinghe S, Mockler JC, Lim R and Wallace EM. The effects of hydroxychloroquine on endothelial dysfunction. Pregnancy Hypertens. 2016;6:259-262. 106. Liu J, Cao R, Xu M, Wang X, Zhang H, Hu H, Li Y, Hu Z, Zhong W and Wang M. Hydroxychloroquine, a less toxic derivative of chloroquine, is effective in inhibiting SARS-CoV-2 infection in vitro. Cell Discov. 2020;6:16. 
107. Kajikawa M, Higashi Y, Tomiyama H, Maruhashi T, Kurisu S, Kihara Y, Mutoh A and Ueda SI. Effect of short-term colchicine treatment on endothelial function in patients with coronary artery disease. Int J Cardiol. 2019;281:35-39.

108. Parchure N, Zouridakis EG and Kaski JC. Effect of azithromycin treatment on endothelial function in patients with coronary artery disease and evidence of Chlamydia pneumoniae infection. Circulation. 2002;105:1298-303.

109. Ruiz-Limon P, Ortega R, Arias de la Rosa I, Abalos-Aguilera MDC, Perez-Sanchez C, Jimenez-Gomez Y, Peralbo-Santaella E, Font P, Ruiz-Vilches D, Ferrin G, Collantes-Estevez E, Escudero-Contreras A, Lopez-Pedrera C and Barbarroja N. Tocilizumab improves the proatherothrombotic profile of rheumatoid arthritis patients modulating endothelial dysfunction, NETosis, and inflammation. Transl Res. 2017;183:87-103.

110. Ahn DG, Shin HJ, Kim MH, Lee S, Kim HS, Myoung J, Kim BT and Kim SJ. Current Status of Epidemiology, Diagnosis, Therapeutics, and Vaccines for Novel Coronavirus Disease 2019 (COVID-19). J Microbiol Biotechnol. 2020;30:313-324. 